\title{
Bacteria as indicators for finding oil and gas reservoirs: A case study of the Bikaner-Nagaur Basin, Rajasthan, India
}

\author{
Mohammed Abdul Rasheed*, Mutnuri Lakshmi, Deshoju Srinu and \\ Anurodh Mohan Dayal \\ Microbiology Laboratory, Petroleum Geochemistry Division, National Geophysical Research Institute, Council for Scientific \\ and Industrial Research (CSIR), Uppal Road, Hyderabad-500606, India
}

(C) China University of Petroleum (Beijing) and Springer-Verlag Berlin Heidelberg 2011

\begin{abstract}
Geo-microbial prospecting for hydrocarbons is an exploration method based on the seepage of light gaseous hydrocarbons from oil/gas reservoirs to the surface and their utilization by hydrocarbon oxidizing bacteria. These bacteria utilize hydrocarbon gases as their sole source of food and are found to be enriched in the near surface soils/sediments above the oil and gas reservoirs. The detection of anomalous populations of n-pentane and n-hexane oxidizing bacteria in the surface soils can help to evaluate the prospects for hydrocarbon exploration. A geo-microbial survey has been carried out in the Bikaner Nagaur basin to investigate the prospects for hydrocarbon exploration. In the present study, bacterial counts for n-pentane utilizing bacteria range between $2.0 \times 10^{2}$ and $1.26 \times 10^{6} \mathrm{cfu} / \mathrm{gm}$ and $\mathrm{n}$-hexane utilizing bacteria range between $2.0 \times 10^{2}$ and $1.21 \times 10^{6} \mathrm{cfu} / \mathrm{gm}$. The bacterial concentration distribution maps show four distinct anomalies in the study area. The possibility of discovering oil or gas reservoirs using the microbiological method is emphasized by the fact that the hydrocarbon-oxidizing bacteria range between $10^{3}$ and $10^{6} \mathrm{cfu} / \mathrm{gm}$ in soil/sediment receiving hydrocarbon micro-seepages. In the present study area of the Bikaner Nagaur basin, n-pentane and n-hexane utilizing bacteria are found between $10^{5}$ and $10^{6} \mathrm{cfu} / \mathrm{gm}$ of soil sample, which is significant and thereby substantiates the seepage of lighter hydrocarbon accumulations from oil and gas reservoirs. Geo-microbial prospecting studies suggest that hydrocarbon micro-seepage of subsurface origin is present in the study area and indicate that the area has positive prospects for petroleum exploration.
\end{abstract}

Key words: Hydrocarbon utilizing bacteria, microbial prospecting, micro-seepage, petroleum exploration

\section{Introduction}

Microbial prospecting method for oil and gas exploration is based on the premise that the light gaseous hydrocarbons migrate upward from subsurface petroleum accumulations by diffusion and effusion (Schumacher and Abrams, 1996), and are utilized by a variety of microorganisms present in the sub-soil ecosystem. The hydrocarbon oxidizing bacteria exclusively use these gaseous hydrocarbons as carbon source for their metabolic activities and growth (Klusman, 1993; Atlas, 1981; 1984). These bacteria are mostly found to be enriched in the shallow soils/sediments above hydrocarbonbearing structures at higher levels in hydrocarbon-prospective areas than non-prospective areas. The microbial anomalies have been proven to be reliable indicators of oil and gas in the subsurface (Sundberg et al, 1994; Tucker and Hitzman, 1994). The microbial prospecting method involves isolation and measurement of hydrocarbon oxidizing bacteria in sub-

*Corresponding author. email: drrasheedmicro@gmail.com

Received August 25, 2010 soil strata for the demarcation of hydrocarbon prospects. The direct and positive relationships between microbial population and hydrocarbon concentration in the soils have been investigated in various producing reservoirs worldwide (Sealy, 1974; Miller, 1976; Rasheed et al, 2007; 2008; Wagner et al, 2002). This technique has been successfully applied in both on land and offshore areas (Beghtel et al, 1987; Nimmi Singh et al, 1999; Wagner et al, 2002; Rasheed et al, 2009). Initially, methane- and later ethane-, propane-, and butane-oxidizing bacteria were exploited for petroleum exploration. If the result of isolation and enumeration of bacteria that can oxidize n-alkanes with chain lengths of 2 to 8 carbon atoms, without any adaptation period, shows the existence of hydrocarbons in the soil/sediment samples, thus it can indicate the presence of oil accumulations in the subsurface (Wagner et al, 2002). An attempt was made by using n-hexane utilizing bacteria as indicator for prospecting of oil and gas deposits (Indrani et al, 1989). Miller (1976) reported a microbial survey of oil fields in USA, in which the microbial activity profile showed a good contrast between oil fields and nearby dry areas. Microbial prospecting methods have been widely used in 
Germany since 1961 . In a study conducted by Wagner et al (2002), a total of 17 oil and gas fields were identified using the Microbial Prospecting for Oil and Gas (MPOG) method and the success rate was reported to be $90 \%$. The microbial prospecting method has been used to prioritize the drilling locations and to evaluate the hydrocarbon prospects of an area (Pareja, 1994). This method can be integrated with geological, geochemical and geophysical methods, thereby reducing drilling risks and achieving higher success in petroleum exploration (Mello et al, 1996; Hitzman et al, 2002; Wagner et al, 2002). Microbiological prospecting is a valuable and less expensive additional exploration tool to evaluate seismic prospects (Pareja, 1994).

In the present study, the microbial prospecting method is applied in the Bikaner Nagaur Basin, Rajasthan for evaluating the prospects for hydrocarbon exploration by investigating the anomalous abundance of n-pentane and n-hexane-oxidizing bacteria of this area.

\section{Geological setting}

The Bikaner Nagaur basin located at $26^{\circ} 10^{\prime}: 30^{\circ} 00^{\prime} \mathrm{N}$ latitude and 71 $31^{\prime}$ : $74^{\circ} 26^{\prime} \mathrm{E}$ longitudes in western Rajasthan, India, is an elongated asymmetrical sedimentary basin trending NNE-SSW and covering an area of over 100,000 $\mathrm{km}^{2}$. The geological map of the Bikaner Nagaur Basin is shown in Fig. 1. The basin continues from northwest Rajasthan, under the semi-desert plains, to northwest Haryana (Sirsa district) and southwest Punjab (Faridkot and Ferozepur districts). The Bikaner Nagaur basin is bounded by the Aravalli mountain range in the east, the Delhi-Lahore subsurface ridge

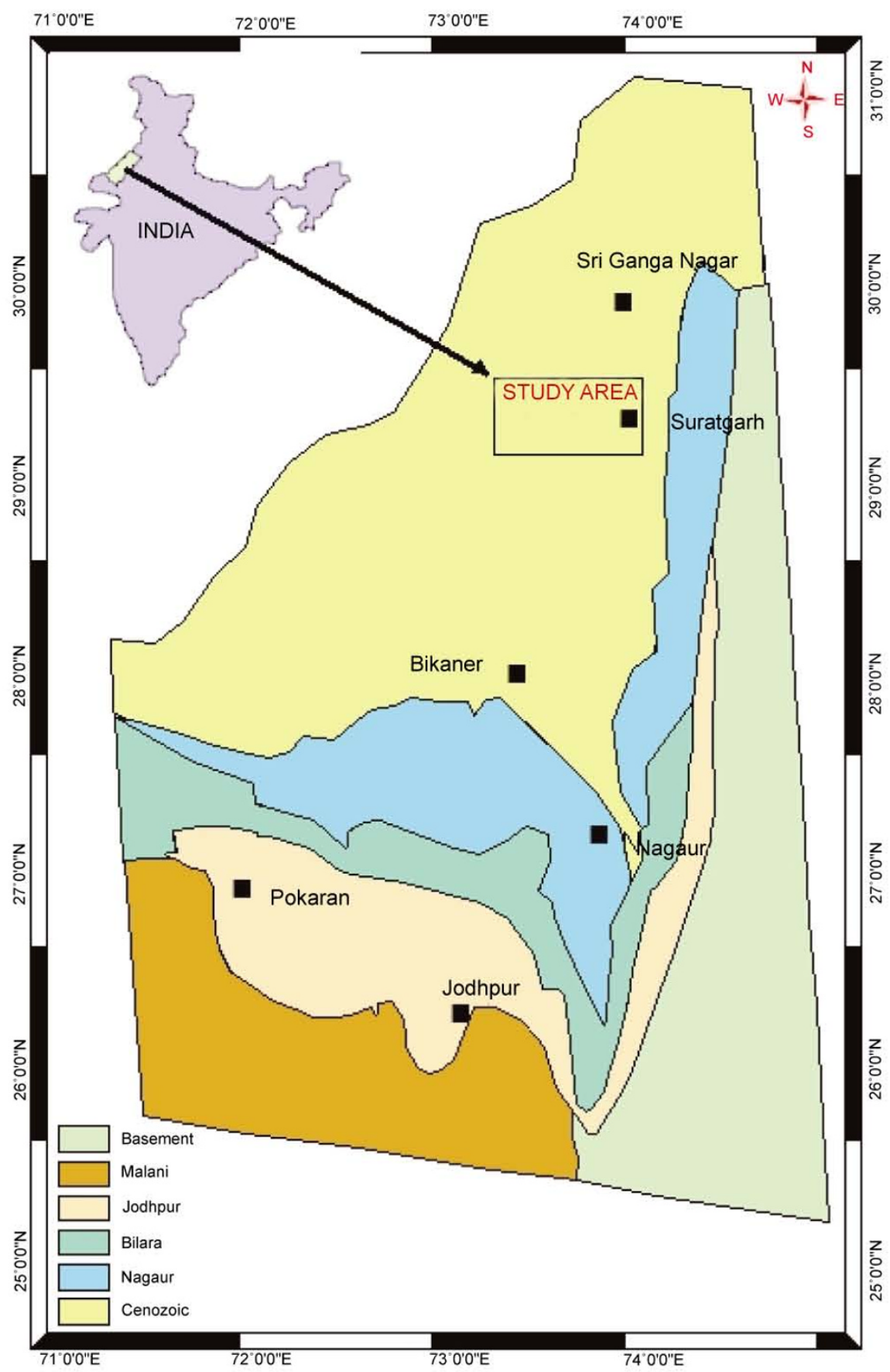

Fig. 1 Geological map of the Bikaner Nagaur Basin of Rajasthan, India showing the study area 
in the northeast and the Devikot-Nachna subsurface high in the southwest. The basin evolution and the paleogeography of the Bikaner Nagaur basin is associated with other sedimentary basins at the west of the Aravalli range and north of the Jodhpur-Pokhran-Chhotan Malani ridge. The initiation of these sedimentary basins is believed to be related to the Precambrian post Delhi orogenic, anorogenic and igneous activities between $940 \pm 20 \mathrm{Ma}$ and $600 \pm 70 \mathrm{Ma}$ (Choudhary et al, 1984). The Bikaner Nagaur basin at the west of Aravalli mountain range, came into existence by the rejuvenation of old Archean and Proterozoic lineaments. Initial rifting caused inter-basinal faults, trending NNE-SSW and resulted in the formation of horst and graben structures. It was followed by large-scale Malani igneous activity. The Malani outpourings were largely fissure-controlled eruptions and related to deepseated tectonic structures trending NNE-SSW. Volcanicity commenced from the north (Tosham Igneous Complex of $940 \pm 20 \mathrm{Ma}$ ) spread westwards (Kirana volcanics of $870 \pm 40$ $\mathrm{Ma}$ ) and culminated in Rajasthan represented by Malani rhyolites of $745 \pm 10 \mathrm{Ma}$ and Jalore Granite of $600 \pm 70 \mathrm{Ma}$. The period from $940 \pm 20 \mathrm{Ma}$ to $600 \pm 70 \mathrm{Ma}$ may, therefore, be considered as the period for the formation and development of the basinal configuration of the large NNE-SSW trending sedimentary basin, which extends from Salt Range in Pakistan, its northern extremity, to the Bikaner Nagaur basin, its southern extremity. Sedimentation in the Bikaner Nagaur basin probably commenced during Late Proterozoic glaciation as is indicated by the presence of Pokhran glacial/fluvioglacial beds over the eroded surface of the Malanis (Khan and Sogani, 1973).

\section{Materials and methods}

\subsection{Sampling}

The microbial prospecting survey was carried out in part of the Bikaner Nagaur Basin of Rajasthan, India lies within $29.25^{\circ}-29.50^{\circ} \mathrm{N}$ latitude and $73.25^{\circ}-73.70^{\circ} \mathrm{E}$ longitude (Fig. 1). Soil sampling was carried out in a grid pattern of $1.1 \times 1.1$ $\mathrm{km}$ interval. A total of 131 soil samples were collected aseptically in pre-sterilized whirl pack bags under aseptic conditions from a depth of about $1 \mathrm{~m}$ and stored at $2-4{ }^{\circ} \mathrm{C}$ till analysis.

\subsection{Experimental methodology}

The soil samples collected from the Bikaner Nagaur Basin were analyzed for n-pentane and n-hexane utilizing bacteria. These two bacteria were isolated separately in an atmosphere of n-pentane and n-hexane using an enrichment culture technique, and measurement of the bacteria was done by the Standard Plate Count (SPC) method. One gram of sediment sample was suspended in $9 \mathrm{~mL}$ of pre-sterilized water for preparation of decimal dilutions $\left(10^{-1}\right.$ to $\left.10^{-7}\right)$. A $0.1 \mathrm{~mL}$ aliquot of each dilution was plated onto Mineral Salts Medium (MSM) containing petri plates (Atlas and Lawrence, 1996). These plates were placed in glass desiccators containing air saturated with n-pentane or n-hexane vapor respectively. These desiccators were kept in a bacteriological incubator at $35 \pm 2{ }^{\circ} \mathrm{C}$ for 10 days. After incubation, the developed bac- terial colonies of n-pentane and n-hexane utilizing bacteria were manually counted using a colony counter and the bacterial colonies were reported in colony forming unit (cfu/gm of soil sample). The bacterial population and anomaly maps were prepared using Golden Surfer 8.0 application software.

\section{Results and discussion}

The bacteria, which are able to utilize n-pentane or n-hexane as a sole carbon source, are merely developed as bacterial colonies on the MSM plates. Control plates were incubated similarly but without n-pentane and n-hexane. During the course of experiment, positive controls of known hydrocarbon oxidizing bacterial strains namely, Mycobacterium sp. MTCC 19 and Pseudomonas sp. MTCC 129 (procured from IMTECH Chandigarh) were inoculated onto MSM plates and incubated along with the test soil samples. The growth was observed in positive controls and in test samples after incubation. Microseepage of subsurface hydrocarbons was identified by determining the anomaly of hydrocarbon utilizing bacteria under a n-pentane or n-hexane atmosphere, hence, in our study the identification of bacterial strains was not carried out.

The bacterial counts in the study area of the Bikaner Nagaur Basin for pentane utilizing bacteria are in the range between $2.0 \times 10^{2}$ and $1.26 \times 10^{6} \mathrm{cfu} / \mathrm{gm}$ and for $\mathrm{n}$-hexane utilizing bacteria are in the range between $2.0 \times 10^{2}$ and $1.21 \times 10^{6} \mathrm{cfu} / \mathrm{gm}$. Statistical analysis of $\mathrm{n}-\mathrm{pentane}$ and n-hexane utilizing bacteria are given in Table 1. Hydrocarbon oxidizing bacterial concentrations are plotted on the surveyed map using Golden Surfer software 8.0. The bacterial concentration distribution maps of n-pentane and n-hexane utilizing bacteria show four distinct anomalies in the studied area (Figs. 2 and 3).

Table 1 Statistical analysis of n-pentane and n-hexane utilizing bacteria in the part of the Bikaner Nagaur Basin, RajasthNote: cfu: colony forming unit

\begin{tabular}{lcc}
\hline \multicolumn{1}{c}{ Parameter } & $\begin{array}{c}\text { n-pentane } \\
\text { utilizing bacteria }\end{array}$ & $\begin{array}{c}\text { n-hexane } \\
\text { utilizing bacteria }\end{array}$ \\
\hline No. of samples & 131 & 131 \\
Minimum & $0.2 \times 102 \mathrm{cfu} / \mathrm{gm}$ & $0.2 \times 102 \mathrm{cfu} / \mathrm{gm}$ \\
Maximum & $1.26 \times 106 \mathrm{cfu} / \mathrm{gm}$ & $1.21 \times 106 \mathrm{cfu} / \mathrm{gm}$ \\
Arithmetic mean & $1.40 \times 105 \mathrm{cfu} / \mathrm{gm}$ & $1.40 \times 105 \mathrm{cfu} / \mathrm{gm}$ \\
Standard deviation & $1.73 \times 105 \mathrm{cfu} / \mathrm{gm}$ & $1.94 \times 105 \mathrm{cfu} / \mathrm{gm}$ \\
Positive samples & $98.48 \%$ & $96.19 \%$ \\
Samples above & & $19.08 \%$ \\
standard deviation & $23.66 \%$ & \\
\hline
\end{tabular}

The hydrocarbon utilizing bacterial counts in three known oil and gas fields are given in Table 2. In the established regions of the Kadi Kalol oil and gas fields of the Cambay basin, the hydrocarbon utilizing bacteria ranged between $10^{6}$ and $10^{7} \mathrm{cfu} / \mathrm{gm}$ of soil. In the other well-known areas, such as the Ponnamanda and Tatipaka gas fields of the Krishna Godavari basin, the hydrocarbon utilizing bacterial counts 


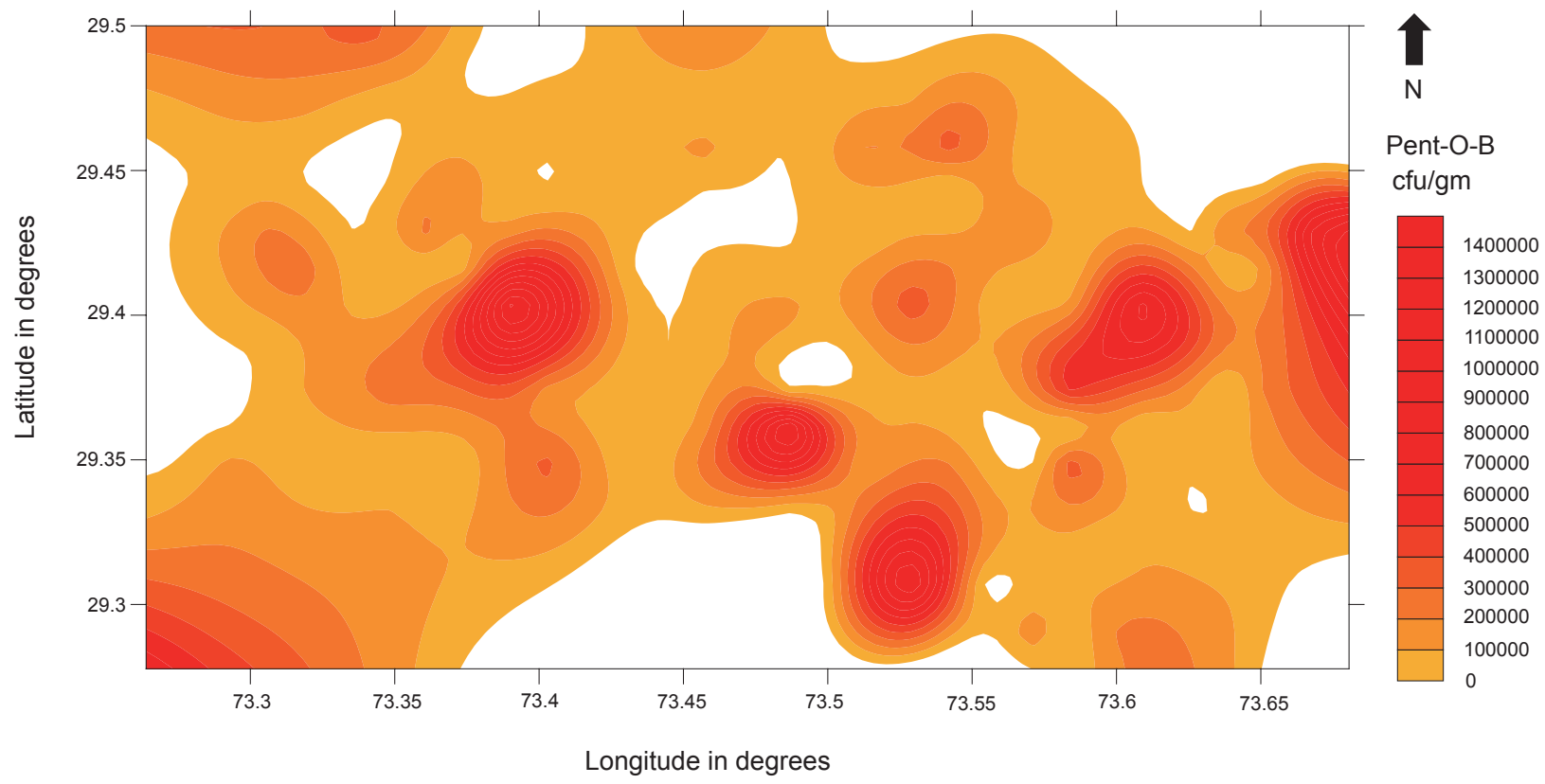

Fig. 2 The n-pentane utilizing bacterial concentration distribution map of the study area

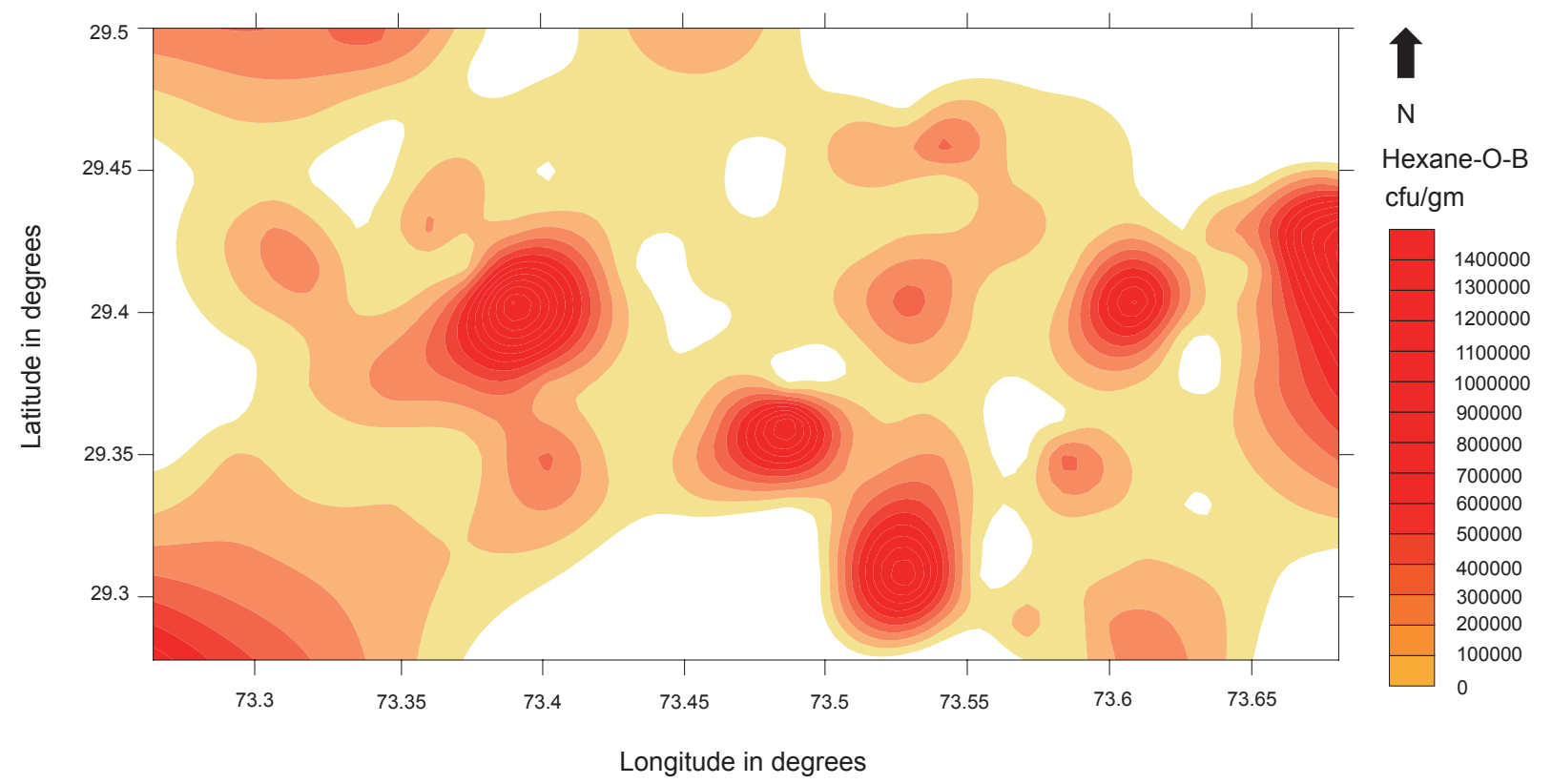

Fig. 3 The n-hexane utilizing bacterial concentration distribution map of the study area

Table 2 Hydrocarbon utilizing bacterial count of various established oil and gas fields and study area

\begin{tabular}{cccc}
\hline Sampling area & $\begin{array}{c}\text { Total no. of } \\
\text { samples }\end{array}$ & $\begin{array}{c}\text { Soil samples showing } \\
\text { bacterial growth } \geq 10^{4}, \%\end{array}$ & $\begin{array}{c}\text { Hydrocarbon utilizing bacteria } \\
\text { (cfu/gm) of soil }\end{array}$ \\
\hline Mehasana (oil/gas fields) & 135 & 92 & $10^{6}-10^{7}$ \\
Jaisalmer (gas fields) & 100 & 80 & $10^{4}-10^{5}$ \\
Krishna Godavari Basin (gas fields) & 150 & 90 & $10^{5}$ \\
Present study area (Bikaner Nagaur Basin) & 131 & 84 & $10^{5}-10^{6}$ \\
\hline
\end{tabular}

of these two areas were found to be $10^{5} \mathrm{cfu} / \mathrm{gm}$ of soil, indicating the adaptation of microbes to utilize hydrocarbon seepage and possible presence of hydrocarbon deposits. The Oil and Natural Gas Commission (ONGC) of India has reported the presence of recoverable deposits of petroleum in these two areas. In the oil fields of Mehsana, Cambay basin, Gujarat, it is found that the number of hydrocarbon utilizing bacteria from a petroliferous area is in the range 
between $10^{6}$ and $10^{7} \mathrm{cfu} / \mathrm{gm}$ of soil. In the Jaisalmer gas fields the number of bacteria per gram of soil was always greater than $10^{4} \mathrm{cfu} / \mathrm{gm}$ of soil. In these three established oil and gas fields of Mehsana, Cambay basin, Jaisalmer basin and Krishna Godavari basin, soil samples showing bacterial growth $\geq 10^{4}$ account for $92 \%, 80 \%$ and $90 \%$ respectively. The bacterial counts of these established oil and gas fields were ranged between $10^{3}$ and $10^{7} \mathrm{cfu} / \mathrm{gm}$, while in the exploratory area, the soil samples showed bacterial growth $\geq 10^{4}$, indicating that oil or gas exist in the latter area, which was eventually found to be correct after drilling operations. The possibility of discovering oil or gas reservoirs by the microbiological method is emphasized by the fact that the count of hydrocarbon-oxidizing bacteria in soil or sediment samples is in the range between $10^{3}$ and $10^{6} \mathrm{cfu} / \mathrm{gm}$ in soil/ sediment receiving hydrocarbon micro-seepages, depending on the ecological conditions (Wagner et al, 2002).

In the study area of the Bikaner Nagaur basin, $84 \%$ of the soil samples show the bacterial growth of $\geq 10^{4}$ per gram of soil, and the hydrocarbon oxidizing bacterial count ranged between $10^{5}$ and $10^{6} \mathrm{cfu} / \mathrm{gm}$ of soil, which is significant and thereby substantiate the seepage of lighter hydrocarbon accumulations from the subsurface petroleum reservoirs. The maps of n-pentane and n-hexane utilizing bacteria of the study area show four distinct microbial anomalies, which confirm the seepage of light hydrocarbons from the subsurface oil/ gas reservoirs. The microbial results show high bacterial concentrations for $\mathrm{n}$-pentane and $\mathrm{n}$-hexane utilizing bacterial populations in the studied area of the Bikaner Nagaur Basin, indicating positive prospects for hydrocarbon exploration.

\section{Conclusion}

The microbiological method of oil prospecting is indirect; it is relatively simple and inexpensive. In most previous investigations methane, ethane, propane or butane oxidizing bacteria were used as indicators with varying success; however the use of $n$-hexane and $n$-pentane utilizing bacterial indicators for oil and gas exploration appears to be simple and cost effective. In the present study area of the Bikaner Nagaur basin, n-pentane and n-hexane utilizing bacteria were found to be present at levels between $10^{5}$ and $10^{6} \mathrm{cfu} / \mathrm{gm}$ of soil sample, which is significant and thereby substantiates the seepage of lighter hydrocarbons from the subsurface. Geo-microbial prospecting studies suggest that hydrocarbon micro-seepage of subsurface origin is present in the study area and indicate that the area has positive prospects for petroleum exploration.

\section{Acknowledgements}

The authors Dr. M.A.Rasheed (Research Associate) and Miss. M.Lakshmi (Senior Research Fellow) are thankful to CSIR for providing fellowships and we are thankful to Dr. Y.J.Bhasker Rao, Director, National Geophysical Research Institute, (CSIR) for granting permission to publish this work. We thank the Secretary, Oil Industry Development Board (OIDB) for a financial grant for setting up the Microbiology laboratory facility. We are thankful to Dr. Kuldeep Chandra, Former Executive Director, KDMIPE, Dehradun for his continuous support and constant guidance.

\section{References}

Atlas R M. Microbial degradation of petroleum hydrocarbons: An environmental perspective. Microbiological Reviews. 1981. 45 (1): 180-314

Atlas R M. Petroleum Microbiology. New York: Macmillan publishing Company. 1984. 692

Atlas R M and Lawrence C P. Handbook of Microbiological Media. New York: CRC Press. 1996. 79

Beghtel F W, Hitzman D O and Sundberg K R. Microbial oil survey technique for evaluation of new field wildcat wells in Kansas. Association of Petroleum Geochemical Explorationists Bulletin. 1987. 3: 1-14

Choudhary A K, Gopalan K and Sastri C. Present status of the geochronology of the Precambrian rocks of Rajastan. Tectonophysics. 1984. 105: 131-140

Hitzman D C, Rountree B A, Tuker J D and Smith S. Integrated microbial and 3-D seismic surveys discover park springs (Conglomerate) field and track microseepage reduction, in Surface exploration case histories. AAPG Studies in Geology No. 48 and SEG Geophysical References Series. 2002. 11: 59-65

Indrani Roy, Sanjay K. Shukla, Ajit K. Mishra, et al. Microbes as an indicator of underground petroleum deposits. Fuel. 1989. 68(3): 311314

Khan E A and Sogani P C. Stratigraphy and sedimentation of TransAravalli Vindhyans of western Rajasthan. Seminar on recent advances in geology of Rajasthan and Gujarat. 1973. 103

Klusman R W. Microbiological Methods: Soil Gas and Related Methods for Natural Resource Exploration. New York: John Wiley and Sons. 1993. 483

Mello M R, Goncalves F T, Babinski N A and Miranda F P. Hydrocarbon prospecting in the Amazon rain forest: Application of surface geochemical, microbiological, and remote sensing methods. AAPG Memoir 66. 1996. 401-411

Miller G H. Microbial survey helps to evaluate oil and gas. Oil and Gas Journal. 1976. 4: 192-202

Nimmi Singh, Kapoor S, Jain M A, et al. Geomicrobial survey for hydrocarbons in Frontier basins of India. Petrotech. 1999. 323-326

Pareja L. Combined microbial, seismic surveys predict oil and gas occurrences in Bolivia. Oil and Gas Journal. 1994. 24: 68-70

Rasheed M A, Veena Prasanna M, Satish Kumar T, et al. Geo-microbial prospecting method for hydrocarbon exploration in Vengannapalli village, Cuddapah Basin, India. Current Science. 2008. 95: 361-366

Rasheed M A, Veena Prasanna M, Dayal A M, et al. Exploration of hydrocarbons using geomicrobial technique in Deccan Syncline, India. Petroview. 2007. 2(4): 25-30

Rasheed M A, Lakshmi M, Patil D J, et al. Geo-microbial studies for Hydrocarbon exploration in sediment samples from southern part of Gulf of Mannar, Kerala Konkan Offshore Basin. Indian Journal of Petroleum Geology. 2009. 17(2): 1-9

Schumacher D and Abrams M A. Hydrocarbon migration and its near surface expression. AAPG Memoir. 1996. 66: 446

Sealy J R. A geomicrobial method of prospecting for oil. Oil and Gas Journal. 1974. 8: 142-46

Sundberg K R, Hitzman D C, Tucker J D, et al. Surface hydrocarbon microseepage detection by microbial survey of the Sorrento Mt. Perl field area, Cheyenne County, Colorado. AAPG Annual Convention Program. 1994. 267

Tucker J and Hitzman D. Detailed microbial surveys help improve reservoir characterization. Oil and Gas Journal. 1994. 6: 65-69

Wagner M, Wagner M, Piske J and Smit R. Case histories of microbial prospection for oil and gas. AAPG studies in Geology No. 48 and SEG Geophysical References Series. 2002. 11: 453-479 